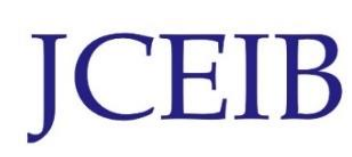

Journal Chemical Engineering and Industrial Biotechnology (JCEIB)

Open Access

Volume 3 pp. 26-36; March 2018

(O) Universiti Malaysia Pahang Publisher

DOI: https://doi.org/10.15282/JCEIB-V3-04.28/3/2018/3.3

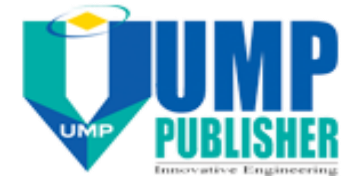

\title{
ENZYMATIC PRODUCTION OF FRUCTOOLIGOSACCHARIDES FROM PHYTOENZYMES OF ANANAS COMOSUS WASTE BY USING RESPONSE SURFACE METHODOLOGY: ONE FACTOR
}

\author{
M.J.Nur Dini ${ }^{\mathrm{a}}$, A.Noormazlinah ${ }^{\mathrm{a}}$, N.H.Hamidi ${ }^{\mathrm{a}}$, M.A. Nurul Aini ${ }^{\mathrm{a}}$, A.M.Mimi Sakinah ${ }^{\mathrm{b}}$ \\ M.F. Ali ${ }^{\mathrm{a}}$ \\ ${ }^{a}$ Faculty of Chemical and Natural Resources Engineering \\ Universiti Malaysia Pahang, 26300 Kuantan. \\ ${ }^{\mathrm{b}}$ Faculty of Engineering Technology \\ Universiti Malaysia Pahang, 26300 Kuantan. \\ * Corresponding author: E-mail: mazlinah @ ump.edu.my \\ Tel.: +609-5492868 Fax.: +606- 1234567
}

\begin{abstract}
Fructooligosaccharides (FOS) are low calorie sweeteners with prebiotic property which is widely used as functional food material.FOS can be produced by using phytoenzymes from Ananas comosus waste. Pineapple (Ananas comosus) fruits are available at most of Asean country. In this work, One Factor at A Time (OFAT) by Response Surface Method (RSM) using Design Expert version 7.0 have been applied to optimize the FOS concentrations by enzymatic reaction of sucrose with phytoenzymes from Ananas comosus waste. The studied variables were: temperature $\left(30-90^{\circ} \mathrm{C}\right), \mathrm{pH}(3-9)$, time of reaction (10-120 minutes), sucrose concentrations $(20 \%-80 \% \mathrm{w} / \mathrm{v})$ and phytoenzymes concentrations $(10 \%-100 \% \mathrm{w} / \mathrm{v})$ of reaction correspondingly. As a result, an optimum condition FOS production was obtained are, time of reaction (100 minutes), temperature $\left(60^{\circ} \mathrm{C}\right), \mathrm{pH}(5.5)$, sucrose concentration $(60 \% \mathrm{w} / \mathrm{v})$, and phytoenzymes concentration $(30 \% \mathrm{w} / \mathrm{v})$, respectively and producing $150.456(\mathrm{~g} / \mathrm{ml})$. This investigation can be further extended to explore the prebiotic potential of synthesized FOS.
\end{abstract}

Keyword: Fructooligosaccharides, Ananas comosus, phytoenzymes, waste, One Factor at A Time, Design Expert.

\subsection{INTRODUCTION}

Recent developments in food industy have heightened the need healthier and low calorie foods. Subsequently, food industry has created different substitution for sweeteners and one of them is the frustooligosaccharides (FOS). These compounds brings numerous health advantages. Moreover, there have been several studies in the literature established that FOS can stimulate enormous benefits properties to the human health. For that purpose, it brings commercially interesting for many applications especially in pharmaceutical and food industries. Previously, there is a large volume of published studies reporting FOS as a valuable source of prebiotic compounds. This is because they can activate the bifidobacteria growth in the human colon, have low caloric values and non-cariogenic properties, help gut absorption of calcium and magnesium, lowering 
plasma levels of phospholipids, triglycerides and cholesterol, and also preferable for formulation of diabetic products (Roberfroid M. 2005; Frank A. 2002; Gibson G et al 2008).

The term of fructooligosaccharides (FOS) refers to oligosaccharides of chain of fructose which contains a single glucose molecule (L'Hocine et al., 2000). Many studies have identified that FOS usually found in a number of some plants and vegetables. For instance, in banana, onion, asparagus roots, artichokes, shallot and wheat (Dohnalek et al., 1998; Flamm et al., 2001). It is be made up of sucrose molecules to which 1,2 or 3 additional fructose units are added by a $\beta$-(2-1)-glycosidic linkage to the fructose unit of sucrose, including 1-kestose $\left(\mathrm{GF}_{2}\right)$, nystose $\left(\mathrm{GF}_{3}\right)$ and $1{ }^{\mathrm{F}}$-fructosylnystose $\left(\mathrm{GF}_{4}\right)$ (Jung et al.,1989). According to Frank (2002) and Ghazi et al (2007), they claimed that FOS can be formed from sucrose transformation by action of fructosyltransferase (FTase) or $\beta$ fructofuranosidase enzymes which is originated from bacterial and fungal sources.

Over the past years, in 1995, the global market for FOS from was estimated to be 20,000 tons (Menrad 2003; Siro et al. 2008). Previously, FOS is produced by fermentation of microorganisms such as Aspergillus niger. However, using microbes are very hard to deal with especially in terms of stability since the macrobes are very sensitive towards environment. It is discovered that, the microbial treatment seems to be a decent option for expanding the level of FOS in a mixture through the removal of mono- and dissacharides, so this process being acceptable to be used during the enzymatic synthesis of FOS. Nonetheless, the utilization of microbial treatments involves a further step of purification for the removal of biomass and metabolic products formed during the fermentation in order to obtain a quality FOS product with few contaminants, and thus expanding the production cost (Sanz et al. 2005; Nobre et al. 2013).Several agricultural by products like cereal bran, corn products, sugarcane bagasse, and by-products of coffee and tea processing industries have been reported in many literature were used as substrates to produce Ftase by A. Oryzae CFR 202.Hence, a natural source such as phytoenzymes from Ananas comosus waste can be used for FOS production since there has been numerous works on the utilization of pineapple waste. It have been used as substrate for bromelain, organic acids, ethanol, and others since these are potential source of sugars, vitamins and growth factors (Larrauri et al., 1997; Nigam, 1999a,b; Dacera et al., 2009). Pineapple on the other hand, is rich in cellulose, hemicellulose and other carbohydrates contents and it was found to be a potential substrate for methane generation by anaerobic digestion and a source of dietary fibre (Tran \& Mitchel, 1995; Rani \& Nand, 2004; Aida et al., 2011; Ketnawa et al., 2011)

Normally, pure sucrose is expensive and the cost to produce FTase by using sucrose is high too. There are some by-product like cereal bran, corn-products, sugarcane molasses and by-products of coffee and tea processing industries were used as a substrate to produce FTase from microorganism (Sangeetha et al., 2003). Thus, this by-product can lower the cost of production of FTase. In Malaysia, the FTase enzyme used to be imported from another country such as Japan, India and United States (Sangeetha et al., 2005). Usually, the cost for production of FOS from commercialized enzyme is high, so by using phytoenzymes from pineapple waste to produce FOS, we can reduce the cost. The significance in this study is the raw material or phytoenzymes used which is a by-product and considered as waste from pineapple. 
Recent research has given attention on optimization of process for improving FOS production. Response surface methodology (RSM) by Design of Expert is a collection of statistical methods for designing experiments, building models, evaluating the effects of various factors and searching for the optimum conditions. According to the findings from most of the researchers, RSM has been effectively used in the optimization of media components in various bioprocesses such as protease (Adinarayana and Ellaiah, 2002), xylanase (park et al., 2002), mycophenolic acid (Sadhukhan et al., 1999) and lactic acid production (Hujanen et al., 2001).

The present study trend is the use of waste material for production of byproducts which will increases high economic returns in many industries.Previously, optimization process in analytical chemistry has been carried out by checking the effect of one variable at a time on an experimental response. While only one parameter study was changed, the other parameters were maintained at a fixed value. This optimization technique is called one factor at a time (OFAT). As studied by Montgometry (1991), OFAT method is the most generally used for optimization process. This strategy comprises of choosing a beginning stage or benchmark level. It can be decided that OFAT is a comparatively simple and straight forward experimental plan, which does not require advance statistical knowledge (Rafiqul and Mimi Sakinah, 2012).

Thus, the study aims to produce FOS from phytoenzymes of pineapple waste via enzymatic reaction with sucrose has been carried out which has good potential for prebiotics uses. One Factor at One Time (OFAT) technique imbedded in Design Expert version 7 had been implemented in this study to screen several factors such as reaction time ( $10-120$ minutes), $\mathrm{pH}(3-9)$, temperature $\left(30-90^{\circ} \mathrm{C}\right)$, phytoenzymes concentrations $(10-100 \% \mathrm{w} / \mathrm{v})$, sucrose concentrations $(20-80 \% \mathrm{w} / \mathrm{v})$ had been used for FOS production. The best of our knowledge, there is no reported studies on production of FOS from phytoenzymes of pineapple waste by OFAT technique.

\subsection{MATERIALS AND METHOD}

The pineapple was collected from Lembaga Perindustrian Nenas Malaysia (LPNM). 1 batch of the sample had the equivalent size about 20 kilograms were collected per time. The fruits which were free from visual damages and diseases were used in the experiments. Authentic pure standards (FOS, sucrose, glucose, nystose,kestose) were purchased from Chemolab Supplies, Malaysia). Other chemicals were of analytical grade (sodium acetate, acetic acid, Dinitrosalicyclic acid, sodium sulphite, sodium hydroxide) purchased from commercial sources in Malaysia (Sigma).

\section{Preparation of phytoenzyme}

The fruits were washed, air dried and then manually peeled. The pineapple meat was cut into small pieces before being blended with distilled water. The resulting from blend was filtered through a filter cloth and then stored at $4^{\circ} \mathrm{C}$. (Ketnawa 2012).

\section{Enzyme assay}

The reaction mixture for the assay activity consisted of $1 \mathrm{ml}$ of $60 \%(\mathrm{w} / \mathrm{v})$ sucrose and $1 \mathrm{ml}$ of phytoenzymes in $0.1 \mathrm{M}$ sodium acetate buffer were mixed and let be react for certain 1hour. After that, $1 \mathrm{ml}$ of Dinitrosalicylic acid (DNS) reagent was added into the mixture. The mixture was heated at $90^{\circ} \mathrm{C}$ for $5-15$ minutes to develop the red-brown colour. Then, one $\mathrm{ml}$ of a $40 \%$ potassium sodium tartrate (Rochelle salt) solution was 
added to stabilize the colour. The absorbance was recorded with a spectrophotometer at $550 \mathrm{~nm}$ after cooling to room temperature in a cold water bath (Sumner et al, 1935). One enzyme unit is defined as the amount of enzyme activity required to produce one $\mu \mathrm{mol}$ of glucose per minute under the conditions described.

\section{HPLC analysis}

The Fructooligosaccharides were analyzed by using high performance liquid chromatography (HPLC). ColumnShodexAsahipak NH $200 \mathrm{P}-50$ 4E, $250 \mathrm{~mm}$ X4.6 mm $\mathrm{X} 5.0 \mu$ with the flow rate that used is $1.0 \mathrm{ml} / \mathrm{min}$, RI detector,injector volume $10 \mu \mathrm{L}$. RI optical unit temperature is $35^{\circ} \mathrm{C}$. Analysis was done by column temperature with $30{ }^{\circ} \mathrm{C}$ and run time 30 mins. The mobile phase reagent is acetonitrile and water To $700 \mathrm{ml}$ filtered acetonitrile, add $300 \mathrm{ml}$ of filtered water, mix and degas. Standard was prepared by dissolving 10mg each of fructose, glucose, and sucrose, kestose, nystose, and GF4 were weighed accurately in $10 \mathrm{ml}$ water. The samples were prepared by dissolving $1.0 \mathrm{~g}$ of the sample in $50 \mathrm{ml}$ water. The column was initially washed with water. Later, the column was treated with acetonitrile at a ratio of (80:20) by using flow rate of $1 \mathrm{ml} / \mathrm{min}$ for 30 minutes. After that, the mobile phase was run for 30 minutes. The blank (water) was injected following the standard preparation (six injections) and sample preparation (two injections). The peak responses were recorded for fructose, glucose, sucrose.

\section{Experimental design}

The OFAT technique was used to screen the reaction condition from enzymatic reaction of phytoenzymes from pineapple waste (meat parts) with sucrose that lead to the highest production of FOS. According to Mussatto et al. 2010 and Sangeetha et al 2004, the factors that are affecting FOS by fermentation were mentioned, such as temperature, $\mathrm{pH}$, and substrate concentration. The variables were time of reaction (10-120 minutes), enzyme concentration $(10 \% \mathrm{w} / \mathrm{v}-100 \% \mathrm{w} / \mathrm{v})$, sucrose concentration $(20 \% \mathrm{w} / \mathrm{v}-80 \% \mathrm{w} / \mathrm{v})$, $\mathrm{pH}(3-9)$, and temperature $\left(30^{\circ} \mathrm{C}-90^{\circ} \mathrm{C}\right)$. Initial $\mathrm{pH}$, substrate concentration, phytoenzyme concentration, time, and temperature are fundamental factors that affecting FOS production. All these important factors were optimized and parameters were selected to find their optimum values for FOS production using RSM.

\section{Standard of FOS production}

The standard reaction mixture contained $1 \mathrm{ml}$ of phytoenzymes and $1 \mathrm{ml}$ of $60 \%(\mathrm{w} / \mathrm{v})$ of sucrose in $1 \mathrm{ml}$ of sodium acetate buffer $\mathrm{pH} 5.5$. The reaction was incubated at $55^{\circ} \mathrm{C}$ for 100 minutes.

\section{Effect of reaction time}

For the time course study, experimental conditions were in the same as the standard of FOS production except that the reaction mixture was incubated at $55^{\circ} \mathrm{C}$ for various periods of time where the times ranged from 10 minutes to 120 minutes.

\section{Effect of sucrose concentration}

In the substrate concentration study, experimental conditions were the same as the standard of FOS production except that different substrate concentration was used where the sucrose concentration range from $20 \%(\mathrm{w} / \mathrm{v})$ to $80 \%(\mathrm{w} / \mathrm{v})$. 


\section{Effect of phytoenzymes concentration}

In the enzyme concentration study, experimental conditions were the same as the standard of FOS production except that different phytoenzymes of A.comosus waste concentrations were used ranged from $10 \%(\mathrm{w} / \mathrm{v})$ to $100 \%(\mathrm{w} / \mathrm{v})$.

\section{Effect of temperature}

In the temperature study, experimental conditions were the same as standard of FOS production except that the reaction mixture was incubated at different temperature where the temperature ranged from $30^{\circ} \mathrm{C}$ to $90^{\circ} \mathrm{C}$.

\section{Effect of $p H$}

In the $\mathrm{pH}$ study, experimental conditions were the same as the method as the standard of FOS production except that the $\mathrm{pH}$ ranges of $\mathrm{pH} 3.0$ to $\mathrm{pH} 6.5$ was used. The buffers $0.2 \mathrm{M}$ that were used: acetate ( $\mathrm{pH} 3.0$ to 5.5) and phosphate ( $\mathrm{pH} 6.0$ to $\mathrm{pH} 9.0)$.

In our experiment, to obtain the maximum production of FOS, the best combination of $\mathrm{pH}$, temperature, sucrose concentration, phytoenzymes concentration, and time of reaction were determined by using RSM. The central points for this design were selected based on results obtained from the experimental results. Table 1 shows the parameter and the optimum condition that were used in the experiments.

\subsection{RESULTS AND DISCUSSION}

\section{The effect of residence time on the FOS production}

The residence time in enzymatic reaction between phytoenzymes of pineapple waste at $55^{\circ} \mathrm{C}$ in $1 \mathrm{ml}$ of $1 \mathrm{M}$ sodium acetate buffer (pH5.5) was used. From the Figure 1 (a), the fructooligosaccharides increased rapidly from 25 minutes to 100 minutes and reaches its maximum value at 100 minutes which was $85 \mathrm{~g} / \mathrm{ml}$. The production of FOS is low from 0 to 25 minutes because at this time the enzyme and substrate still bind to each other. A considerable amount of FOS concentration was released after 25 minutes of reaction time. This behaviour indicates that the enzymatic reaction between sucrose and phytoenzymes from pineapple starting to occur. Enzymatic reaction of transfructosylation process involves the basic idea of key and lock reaction between the enzyme and substrate. Longer period of time required to form more FOS from the substrate and this phenomenon clearly shown after it reaches the maximum production of FOS at100 minutes. However, after reaching its maximum point of production, the production of FOS will decrease. This is because due to saturation between enzyme and substrate. Different organisms have different reaction time for optimum production of FOS. As being studied by A.B. Dhake et al 2005, $P$. purpurogenum was grown for the period of 10 days. The organisms like $A$. pullulans, M. michei, A. oryzae and A. flavus showed maximum extracellular and intracellular sucrose hydrolytic enzyme production on day 2, 4, 5 and 5 respectively. Meanwhile, study by Sangeeta et al 2003 found that there are organisms which produced maximum intracellular and extracellular enzyme on the same day.M. michei and $A$. pullulans showed maximum extracellular and intracellular fructosyltransferase production on day 4 and day 2 respectively.

At the model level, the correlation measures used to estimate the regression equation are the multiple correlation coefficient $\mathrm{R}$ and determination coefficient $\mathrm{R}^{2}$. The closer the 
value of $\mathrm{R}^{2}$ is to 1 , the better the correlation between the measured and the predicted values. In this experiment, the value of the determination coefficient, $\mathrm{R}^{2}=0.998$, being measured of fit for the model. The observed optimum reaction at 100 minutes was further optimized by Fractional Factorial Design (FFD) and Response Surface Methodology (RSM).

\section{The effect of sucrose concentration on FOS production}

Transfructosylation reaction of fructooligosaccharides formation is mainly dependent on substrate concentration. Effect of various sucrose concentrations on fructooligosaccharides production was studied by analyzing the various saccharide compositions in the reaction mixture. The amount of fructooligosaccharides produced in the reaction mixture was proportional to the initial concentration of sucrose. Based on Figure 1 (b), as the sucrose concentration was increased, the amount of fructooligosaccharides in the reaction mixture was increasing too. The yield of fructooligosaccharides is the highest at $60 \%$ (w/v) of sucrose concentration which is 46 $\mathrm{g} / \mathrm{mL}$. However, the production of fructooligosaccharides depleted when the sucrose concentration more than $60 \%(\mathrm{w} / \mathrm{v})$ is used. When $20 \%(\mathrm{w} / \mathrm{v})$ and $40 \%(\mathrm{w} / \mathrm{v})$ sucrose was used, moderate amount of fructooligosaccharides formation were seen. Sucrose was rapidly converted into glucose and low concentration of fructooligosaccharides formation was observed $14.88 \% \mathrm{~g} / \mathrm{mL}$ and $39 \% \mathrm{~g} / \mathrm{mL}$ respectively. This is due to low sucrose concentration favoured the reaction to proceed faster thus producing more nystose (Sangeeta et al,2004). Increasing in length of fructose chains decreases sweetening power of fructooligosaccharides. High sucrose concentrations above $60 \%$ (w/v) may causes saturation of enzyme and decreases fructooligosaccharides formation (Fernandez et al, 2004). Fructooligosaccharides by-products like glucose was seen highest in case of $50 \%$ $(\mathrm{w} / \mathrm{v})$ and $60 \%(\mathrm{w} / \mathrm{v})$ sucrose as substrate because due to transfructosylating reaction glucose remains accumulated while fructose transfers to another sucrose molecules and large oligomers like kestose (GF2), nystose (GF3) and 1- $\beta$ fructofuranosyl nystose (GF4) are formed. Increasing substrate concentration will increases the rate of reaction too. This is because more substrate molecules will be colliding with enzyme molecules, so more products will be formed. However, after a certain concentration, any increase does not bring any effects on the rate of reaction, since substrate concentration will no longer be the limiting factor. The enzymes will effectively become saturated and will be working at their maximum possible rate.

Based on the result,the values of "Prob > F" less than 0.0500 indicate model terms are significant. In this experiment, the value of the determination coefficient, $\mathrm{R}^{2}=0.9979$ which is near to 1 , being a measure of fit for the model, thus, this $60 \%(\mathrm{w} / \mathrm{v})$ of the sucrose concentration was further utilized for optimum production of FOS in FFD and CCD statistical analysis.

\section{The effect of pH on FOS production}

$\mathrm{pH}$ range from 3 until 9 were used in this experiment. For $\mathrm{pH} 3$ to 5.5, sodium acetate buffer solution was used, while for $\mathrm{pH} 6$ until 9, phosphate buffer solutions was used. As shown in Figure 1 (c), the production of fructooligosaccharides from enzymatic reaction from phytoenzymes of Ananas comosus with sucrose is optimal at $\mathrm{pH}$ range of 5.0 to 6.0. Similarly, fructosyltransferases from fungi are most active in the $\mathrm{pH}$ range of 5.0 to 6.0 (Hidaka, H et al 1988; Hang, Y.D et al 1995; Yun, J.W et al 1993. According to Mairano 
et al 2008, and Antosova $\mathrm{M}$ et al, 2001, FTase has the optimal $\mathrm{pH}$ is between 4.5 and 6.5.The research studied by Ueda,S. et al (1982) also showed that the optimum initial pH for fructosyltransferase production by P. purpurogenum was found to be 5.5. Studies by C.Uma et al 2010 also showed that the peak of enzyme production was observed at $\mathrm{pH} 5$ for all selected substrates which are using fruit peel waste (orange, pineapple and pomegranate). The influence of $\mathrm{pH}$ of the cultivation medium may be related directly with the stability of enzyme. At $\mathrm{pH} 7$, the concentration of FOS starts to drop. The graph shows decline in enzyme activity on increasing the $\mathrm{pH}$, especially after $\mathrm{pH}$. This shows that enzyme is not stable towards alkaline conditions so the sucrose inversion efficiency is also affected in direct way (Balasundaram, B et al, 2001).The transfructosylating yield at this optimum $\mathrm{pH}$ resulted $66.05 \%(\mathrm{w} / \mathrm{v})$ of fructooligosaccharides formation at $24 \mathrm{~h}$ of enzyme substrate reaction which were significantly $(\mathrm{P}<0.05)$ more than other $\mathrm{pH}$ values. Different enzymes have different their own optimum $\mathrm{pH}$ values. At the Optimum $\mathrm{pH}$, the rate of reaction is at an optimum condition too. Any changes in $\mathrm{pH}$ above or below the optimum will bring a changes, which is might decrease in the rate of reaction, since more of the enzyme molecules will have active site whose shape are not complementary to the shape of their substrate.

From the ANOVA analysis, the prob $>\mathrm{F}$ value is greater than 0.0500 , indicates that the model is not significant. The value of the determination coefficient, $\mathrm{R}^{2}=0.5893$ is not fit for the model. The lack of fit value of 0.24 implies the lack of fit is not significant relative to the pure error. There is $80.40 \%$ chance that a lack of fit F-value this large could occur due to noise. From the study, the yield of FOS was not significantly affected by the changes of $\mathrm{pH}$. This is due to the only slight fluctuation which was observed from the $\mathrm{pH}$ data. Therefore, $\mathrm{pH}$ was not continued for optimized process.

\section{The effect of temperature on FOS production}

The optimal temperature for fructooligosaccahrides production was $60^{\circ} \mathrm{C}$ after 100 minutes of reaction. The enzyme activity was not significant at high temperature because of high temperature denaturation of active site. (Russo, P., et al, 1996). Besides that, as temperature increase, more molecules have enough kinetic energy to undergo the reaction. If the temperature is raised above the ideal point, the kinetic energy of the enzyme and the water molecule is so great that the structure of the enzyme molecules start to be distrupted (Switzer and Garrity,1999). Referring to Figure 1 (d), the increasing in temperature will increases transformation rate of reaction but sharply decline after reaching its maximal value. The transfructosylating activity reached maximum at $55^{\circ} \mathrm{C}$ which is significantly $(\mathrm{p}<0.05)$ better yield of fructooligosaccharides formation as compared to other temperatures. As the reaction temperature increased minimum time is required to reach the maximum production of FOS. Our results are supported by which observed $55^{\circ} \mathrm{C}$ at optimal temperature for fructooligosaccharides production in Penicillium rugulosum but differ from results which observed $60-65^{\circ} \mathrm{C}$ thermal stability of crude FTase in Aspergillus niger and Aureobasidium pullulans respectively. Besides that, research by N.A. Mohd Zain et al, 2010 also found that the ideal temperature for immobilized enzyme using hydrolysis of liquid pineapple waste is $50^{\circ} \mathrm{C}$ which is more similar to free invertase at optimum temperature. It has been observed that many fructooligosaccharides producing enzymes have optimal temperature in the range of $50^{\circ} \mathrm{C}$ to $55^{\circ} \mathrm{C}$. However in some cases the optimum temperature of FTase remarked up to $65^{\circ} \mathrm{C}$. It may be due to high sucrose concentration in reaction mixture prevents fast inactivation of enzyme due to stabilizing effect of high saccharide on FTase activity. 
From the ANOVA analysis, the model F-value of 48.38 implies the model is significant. There is only a $0.53 \%$ chance that a "Model F-Value "his large could due to noise. Besides that, prob $>\mathrm{F}$ value is lower than 0.0500 which is indicates that the temperature is significant in this experiments. The lack of fit F-value of 1.00 implies that the lack of fit is not significant relative to the pure error. There is $42.28 \%$ chance that a lack of fit Fvalue this large could occur due to noise. Meanwhile, the value of the determination coefficient, $\mathrm{R}^{2}=0.9784$ being a measure of fit for the model. Thus, the temperature was at $55^{\circ} \mathrm{C}$ and was further utilized for optimum production of FOS in FFD and CCD statistical design.

\section{The effect of phytoenzymes concentration from Ananas comosus on FOS production}

The fructooligosaccharides were not produced when there is no phytoenzymes in the reaction. As the phytoenzyme concentration was increased, the amount of fructooligosaccharides produced in the reaction is increased too. The amount of fructooligosaccharides is proportional to the phytoenzymes concentration. From the graph shown, the highest production of FOS is detected when the phytoenzymes with $10 \%(\mathrm{w} / \mathrm{v})$ concentration was used. The optimum production of FOS is when $30 \%(\mathrm{w} / \mathrm{v})$ concentration of phytoenzymes was used. After that, the production of FOS starts to depleted when the higher amount of phytoenzyme concentration is increased. This is because the binding of substrate-enzyme has reached the maximum reaction. By increasing the enzyme concentration, the rate of reaction will be increasing too. This is because as more enzymes will be colliding with substrate molecules. Reseach by Deepa C. et al, 2014 also showed that at higher concentrations of enzyme (more than $6 \mathrm{U} / \mathrm{mL}$ ), the maximum FOS yield was reached in relatively shorten the reaction time. However, increasing enzyme concentration led to an increase in the FOS yield initially and thereafter reached a plateau beyond enzyme concentration of $2 \mathrm{U} / \mathrm{mL}$. In batch studies enzymes are not consumed during reaction and hence the number of active sites is fixed throughout a particular run. At lower enzyme concentrations, the same active sites get freed and successively reutilized in a cycle thereby increasing the reaction time to reach maximum FOS yield.

The model F-value of 71.35 implies the model is significant. There is only a $0.27 \%$ chance that a "Model F-value" this large could occur due to noise. Besides that, the prob $>$ F value is less than 0.0500 which is 0.0027 and indicates that the model terms are significant. The lack of fit value of 5.33 implies the lack of fit is not significant relative to the pure error. There is a $14.72 \%$ chance that a lack of Fit F-value this large could occur due to noise. Meanwhile, the value of the determination coefficient, $\mathrm{R}^{2}=0.9862$ being measure of fit for the model.Thus, the amount of phytoenzymes concentrations $30 \%(\mathrm{w} / \mathrm{v})$ was further for the optimization process. 
Journal of Chemical Engineering and Industrial Biotechnology V3(2018)37-50
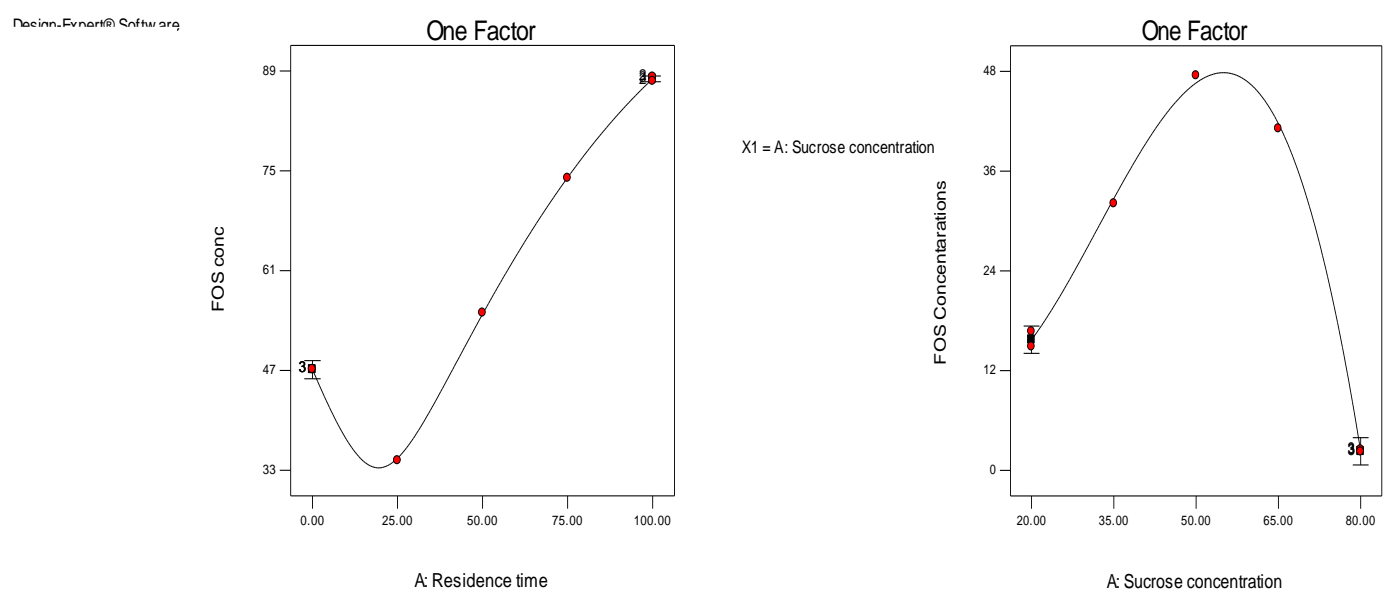

Figure 1 (a)

Figure 1 (b) 
Journal of Chemical Engineering and Industrial Biotechnology V3(2018)37-50

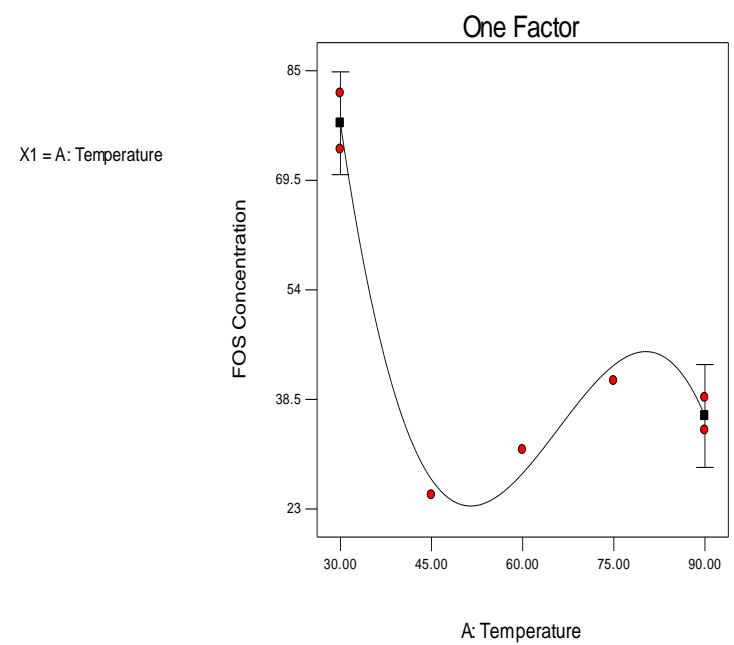

Design-Expert@ Softw are

FOS concentration

- Design Points

$\mathrm{X} 1=\mathrm{A}: \mathrm{pH}$

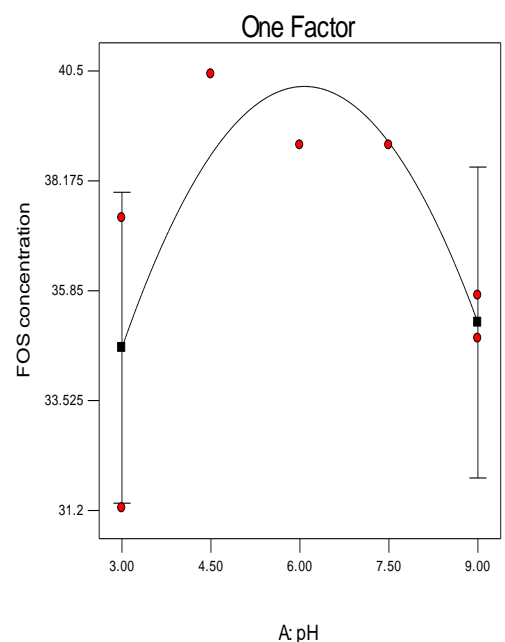

Figure 1 (d)

Figure 1 (c)

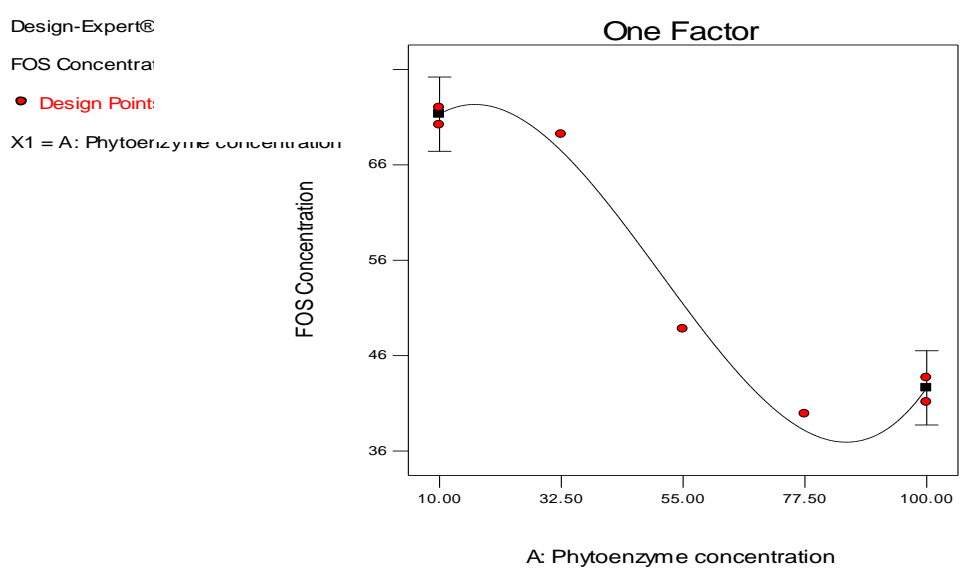

Figure 1 (e)

Figure 1: Graph plot for OFAT results showing the reaction time, sucrose concentration 
, phytoenzyme concentration, $\mathrm{pH}$, and temperature on FOS production by enzymatic rea ction using phteoenzymes of A. comosus waste.

Table 1: Parameters involved in the experiments with suitable range and optimum conditions

\begin{tabular}{lllll}
\hline Parameters & Unit & $\mathbf{- 1}$ & $+\mathbf{1}$ & $\begin{array}{l}\text { Optimum } \\
\text { condition }\end{array}$ \\
\hline $\begin{array}{l}\text { Time of reaction } \\
\text { pH }\end{array}$ & Minutes & 10 & 120 & 100 \\
Temperature & $\mathrm{pH}$ & 3 & 9 & 5.5 \\
$\begin{array}{l}\text { Sucrose } \\
\text { concentration }\end{array}$ & $\%(\mathrm{w} / \mathrm{v})$ & 30 & 90 & 60 \\
$\begin{array}{l}\text { Phytoenzymes } \\
\text { concentration }\end{array}$ & $\%(\mathrm{w} / \mathrm{v})$ & 10 & 80 & 60 \\
\hline
\end{tabular}

Table 2: Analysis of variance (ANOVA)for the selected model

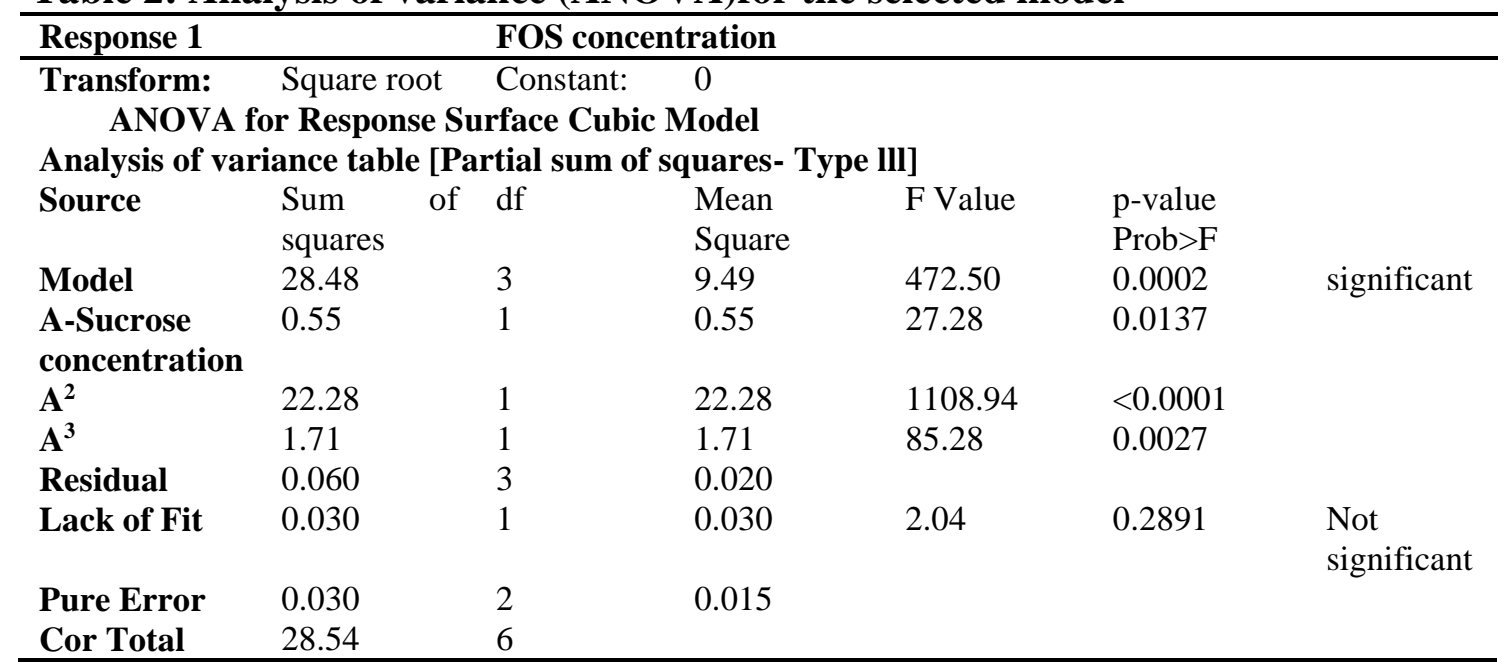

Analysis of the experimental data was systematically conducted as an initial screening process by examining the effects and interactions of all factors involved.A stastical testing using Fisher's statistical test for ANOVA was employed for the determination of significant variables where the degree of significance was ranked based on the value of F-ratio. As matter of fact the larger the magnitude of the F-value and correspondingly the smaller the "Prob $>$ F" Value, the more significant are the correspomding model and the individual coefficient.

The observed optimum reaction time, substrate concentration, phytoenzyme concentration, $\mathrm{Ph}$ and temperature, found that OFAT method were 100 minutes, $60 \%$ $(\mathrm{w} / \mathrm{v}), 30 \%(\mathrm{w} / \mathrm{v}), 5.5$ and $60^{\circ} \mathrm{C}$ correspondingly. These conditions yielded a maximum range of Fos. The OFAT study demonstated that the production of FOS by enzymatic reaction of phytoenzymes of A.comosus waste were influenced by reaction time, substrate concentration, phtyoenzyme concentration, $\mathrm{pH}$ and temperature, which are 
similar to previous research report (Musatto et al., 2009).

\subsection{CONCLUSIONS}

The main goal of this work was to explore the capability of phytoenzymes from pineapple waste to produce FOS by enzymatic reaction with sucrose as substrate. The OFAT technique in experimental design helped to find the significant process parameters. The best results were achieved at $\mathrm{pH}=5.5$, temperature at $60^{\circ} \mathrm{C}$, time of reaction at 100 minutes, sucrose concentration at $60 \%(\mathrm{w} / \mathrm{v})$, phytoenzymes concentration at $30 \%$ $(\mathrm{w} / \mathrm{v})$.The total FOS production yield obtained in the optimum operation conditions was found to be in accordance with the expected value predicted by the model, showing that the model was well fitted to the experimental data and thus describing accurately the studied region. Furthermore, it is important to note that this production was obtained in a one-stage process, thus this study can be as the preliminary study before process development of FOS.It can be concluded that, phytoenzymes of pineapple waste is possible to be used in enzymatic reaction for the FOS production due to low cost, worldwide abundance and high content of sucrose. Thus, environmentally polluting byproducts can be changed into products with a higher commercial value than the main product.

\subsection{ACKNOWLEDGEMENTS}

Authors gratefully acknowledge my supervisor, Dr Noormazlinah Bt Ahmad, Dr. Norhanimah Bt Hamidi, Faculty of Chemical Engineering and Natural Sources, Universiti Malaysia Pahang for the knowledge and for the support. Besides, I want to thank you to Ministry of Malaysia Education for the financial support for this research.

\subsection{REFERENCES}

A.B. Dhake. \& M.B.Patil, (2007). Effect of substrate feeding on production of fructosyltransferase by Penicillium purpurogenum. Brazilian Journal of Microbiology. 2 (38).

Adinarayana K, Ellaiah P. (2002). Response surface optimization of the critical medium components for the production of alkaline protease by a newly isolated Bacilus sp. J.Pharm. Pharm. Sci. 5(3):272-278.

Aida, H.I., Mahanom, H.\& Norgartini, A.S. (2011). Dietary fibre powder from pinapple by-product as a potential functional food ingredient. Acta Horticulturae 902: 565-568.

A.M.P. Santos \& F. Maugeri. (2002). Production of syrup sugar with fructose and glucose enriched or not with fructooligosaccharides from sucrose. Brazil patent office PI 0202.602-3.

Antosova M, Polakovic M. (2001). Fructosyltransferases:. The enzymes catalyzing production of fructooligosaccharides. Chem Pap. 55:350-358.

Balasundaram, B. \& A.B. Pandit (2001). Significance of location of enzymes on their release during microbial cells disruption. Biotech. Bioeng.75:607-614.

C. Uma, D.Gomathi, C.Muthulakshmi, \& V.K.Gopalakrishnan.2010. Production, Purification and Characterization of Invertase by Aspergillus flavus using fruit peel waste as substrate. Advances in Biological Research 4(1:31-36

Dacera D.D.M., Babel S. \& Parkpian P. (2009). Potential for land application of contaminated sewage sludge treated with fermented liquid from pineapple wastes. J. of Hazardous Materials.167:866872.

Deepa C. Khandekar,Tapas PalaiAman Agarwal\&Prashant K. Bhattacharya.(2014).Kinetics of sucrose conversion to fructo-oligosaccharides using enzyme (invertase) under free condition. Bioprocess and Biosystem Engineering. 37: 2529-2537

Del-Val, M.I. \& C.Otero. (2003). Biphasic aqueous media containing polyethylene glycol for the enzymatic synthesis of oligosaccharides from lactose. Enzyme Microbe. Technol. 33:118-126.

Dohnalek, M.I.H., K.M. Ostrom \& M.D. Hilty, (1998). Use of indigestible oligosaccharides to reduce the incidence of otitis media. US Patent 5849324. http://www.google.com/patents/US5849324.

Fernández, R.C., B. Guilarte, A. Juárez \& J. Martinez.( 2004), J. Chem. Technol. Biotechnol.79:268-272

Flamm, G., W. Glinsmann, D. Kritchevsky, L. Prosky \& M. Roberfroid, (2001). Inulin and Oligofructose 
as dietary fiber: A review of the evidence. Crit. Rev. Food Sci. Nutr., 41: 353-362.

Frank, A. (2002). Technological functionality of inulin and oligo-fructose. Br. J.Nutr., 87:287-291.

Ghazi.,Fernandez-Arrojo A.L., Arellano H.G., Ferror M., Ballesteros A. \& Plou F.J.,(2007). Purification and kinetic characterization of a fructosyltransferase from Aspergillus aculeuteus, J.Biotechnol., 128: 204-211.

Gibson, G.R., Probert, H.M., Van Loo, J., Rastall, R.A.,\& Roberfroid, M. (2004). Dietary modulation of the human colonic microbiota: updating the concept of prebiotics. Nutrition Research Reviews.17: 259-275.

H.I.Aida, H.Mahanom \& A.S. Norhartini. (2011). Dietary Fibre Powder from Pineapple By-Product as a Potential Functional Food Ingredient. Food Technology Research Centre Malaysian Agricultural Research and Development Institute (MARDI).

Hang, Y.D.,\& Woodams, E.E. (1995).Fructosyltransferase activityof commercial enzyme preparations used in fruit juice processing. Biotechnol. Lett. 17:741-745.

Hidaka, H., Hirayama, M., \& Sumi, N. (1988). A Fructooligosaccharide-Producing Enzyme From Aspergillus-Niger Atcc-20611. Agricultural and Biological Chemistry. 52: 1181- 87.

Hujanen M, Linko S,Linko YY, Leisola M. (2001). Optimization of media and cultivation conditions for L. $(+)($ S)-lactic acid production by Lactobacillus casei NRRL B-441. Appl. Microbiol. Biotechnol. 56(1-2): 126-130.

Jung KH, Yun JW, Kang KR,Lim JY,Lee JH. (1989). Mathematical model for enzymatic production of fructooligosaccharides from sucrose. Enzyme Microb Technol. 11 (8): 491-494.

Ketnawa, S., Rawdkuen, \& S., Chaiwut,P. (2012). Pineapple waste: A potential source for bromelain extraction. Food and bioproducts processing.90: 385-391.

Ketnawa, S., Rawdkuen, S. 2011. Application of bromelain extract for muscle foods tenderization. Food Nutri. Sci. 2: 393-401.

Larrauri J.A., Ruperez P. \& Calixto F.S. (1997). Pineapple shell as a source of dietary fiber with associated polyphenols. J.of Agri. And Food Chem., 45:4028-4031.

L'Hocine, L., Wang, Z., Jiang, B. \& Xu, S., (2000).J. Biotechnol. 81(73).

M. Antosova \& M. Polakovic. (2001).Fructosyltransferases: The enzyme catalysing production of fructooligosaccharides. Chem. Pap. 55(6):350-358.

Maiorano, A. E., Piccoli, R. M., Silva, E. S., \& Rodrigues, M. F. A. (2008). Microbial production of fructosyltransferases for synthesis of pre-biotics. Biotechnology Letters. 30:1867-1877.

Menrad, K.(2003). Market and marketing of functional food in Europe. Journal of Food Engineering.

Montgomery DC. (1991).Design and Analysis of Experiments. 3th Ed. New York: John Wiley \& Sons.

Mussatto,S.I. \& Teixeira,J.A. (2010).Increase in the fructooligosaccharides yield and productivity by solidstate fermenttaion with Aspergillus japonicus using agro-industrial residues as support and nutrient source. Biochemical Engineering Journal,. 53:154-157.

N.A.Mohd Zain, M.S.Suhaimi \& Ani Idris. (2010). Hydrolysis of liquid pineapple waste by invertase immobilized in PVA-alginate matrix. Biochemical Engineering Journal. 50: 83-89.

Nigam, J.N. (1999b). Continous cultivation of the yeast Candida Utilis at different dilution rates on pineapple cannery waste. World J. Microbiol. Biotechnol. 15: 693-696.

Nobre,C., Teixeira, J. A., \& Rodrigues, L. R. (2013). New trends and technological challenges in the industrial production and purification of fructo-oligosaccharides, Critical Reviews in Food Science and Nutrition.

Park YS, Kang SW,Lee JS, Hong SI, Kim SW (2002). Xylanase production in solid state fermentation by Aspergillus niger mutant using statistical experimental designs. Appl.MiCROBIOL. Biotechnol. 58(6): 761-766.

R.G. Crittenden \& M.J. Playne,(1996).Production, properties and applications of food-grade oligossacharides, Trends Food Sci. Technol. 7:353-361.

R.J. Palframan, G.R. Gibson \& R.A. Rastall. (2002). Effect of pH and dose on the growth of gut bacteria on prebiotic carbohydrates in vitro, Anaerobe. 8:287-292

Rafiqul, I.S.M. \& Mimi Sakinah,A.M. (2012). Kinetic studies on acid hydrolysis of meranti wood sawdust for xylose production. Chemical Engineering Science. 71: 431-437.

Rani D. S., \& Nand K. (2004). Ensilage of pineapple processing waste for methane generation. Waste Management, 24: 523-528.

Roberfroid, M,N., Delzenne, P.Cousesement \& J.V.Loo.(1998).Prevention of mammary carcinogenesis and breast cancer treatment. US Patent 5721345.

Russo,P., A.Garofalo, U.Bencivenga, S. Rossi, D.Castagnoto, A.D’Acunzo, F.S. Gaeta \& D.G.Mita (1996). A non-isothermal bioreactor utilizing immobilized baker's yeast cells: A study of the effect on invertase activity. Biotechnol.Appl. Biochem., 23: 141-148. 
Sadhukan AK,Ramana Murthy MV, Ajaya Kumar R, Mohan EVS, Vandhana G, Bhar C, Venkateswara Rao K (1999). Optimization of mycophenolic acid production in solid-state fermentation using response surface methodologu. J.Ind.Microbiol. Biotechnol. 22(1):33-38.

Sangeetaa P, Ramesha M, \& Prapullaa S. (2005c). Recent trends in in the microbial production, analysis and application of fructooligosaccharides. Trends in Food Science \& Technology. 16: 442-457.

Sangeetha, P.T.; Ramesh, M.N.\&Prapulla, S.G.(2003).Microbial production of Fructooligosaccharide. Asian. Jr. of Microbiol. Biotech.Env. Sc., 5: 313-318.

Sangeetha,P.T., Ramesh, M.N. \& Prapulla,S.G. (2005b). Maximization of fructooligosaccahrides production by two stage continuous process and its scale up. Journal of Food Engineering, 68:57-64.

Sangeetha,P.T., Ramesh,M.N. \& Prapulla,S.G.(2004a).Production of fructooligosaccharides by fructosyl transferase from Aspergillus oryzae CFR 202 and Aureobasidium pullulans CFR 77. Process Biochemistry, 39: 753-758.

Sanz, M. L., Polemis, N., Morales, V., Corzo, N., Drakoularakou, A., Gibson, G. R., \& Rastall, R. A. (2005).In Vitro Investigation into the Potential Prebiotic Activity of Honey Oligosaccharides. Journal of Agricultural and Food Chemistry. 53: 2914-21.

Siró, I., Kápolna, E., Kápolna, B., \& Lugasi, A. (2008). Functional food. Product development, marketing and consumer acceptance-A review Appetite. 51: 456-467.

Sumner, J.B. \& S.F. Howell. (1935). A method for determination of saccharase activity. J.Biol.Chem., 108:51-54.

Switzer, R.L. \& Garrity, L.F. (1999). Experimental Biochemistry, vol. 2. W.H. Freeman, New York

Tran,C.T. \& Mitchell, D.A. (1995). Pineapple waste- a novel substrate for citric acid production by solid state fermentation. Biotechnology Letters, 17:1107-1110.

Ueda, S.; Fujio, Y. \& Lim, J.Y. (1982). Production and some properties of pectic enzymes from Aspergillus orizae A-3. J. Appl. Biochem. 4: 5240-5242.

Yun J.W., Noh J.S., Lee M.G \& Song S.K. (1993).Production of fructooligosaccahrides by the mixed Enzyme system of fructosyltransferase ad glucose isomerase, J.Korean Inst. Chem. 31:846851.Yun, J. W., (1996).,Enzyme Microb. Technol. 19:107-117 